\title{
Determinants of Income Inequality in Yogyakarta Province
}

\author{
Rizka Yuliani ${ }^{1}$, Yozi Aulia Rahman ${ }^{1, *}$, Dini Nuraini ${ }^{1}$, Khusnul Khotimah ${ }^{1}$ \\ ${ }^{1}$ Faculty of Economics, Universitas Negeri Semarang \\ *Corresponding author.Email: yoziaulia@mail.unnes.ac.id
}

\begin{abstract}
The purpose of this study is analyze the effect of population, GRDP, human development index, and district/city minimum wages on income inequality in Yogyakarta Province. This research uses quantitative methods with panel data, which is a combination of cross-section data from 5 regencies/cities in Yogyakarta Province and time-series data for the period 2011-2017. The results showed that the population and GRDP variable has a negative and not significant effect, the human development index variable has a significant negative effect, while the district/city minimum wage variable has a not significant positive effect.
\end{abstract}

Keywords: Income Inequality, Population, Human Development Index, Minimum Wage

\section{INTRODUCTION}

Development is a multidimensional process that involves a various fundamental changes in the social order, attitudes of society, and national institutions such as acceleration of economic growth, changing inequality, and reducing poverty [1]. One of the facts of development in Indonesia is the occurrence of development gaps caused by differences in growth rates between regions [2].

Indonesia is an archipelago which consists of five major islands, namely Java Island that consists of DKI Jakarta, Banten, West Java, Central Java, DI Yogyakarta, and East Java Provinces. Java Island is the largest contributor to Indonesia's GDP. Therefore, all economic activities are centered on the island of Java and serve as a magnet for the Indonesian economy.

The average value of GDP in Indonesia amounted to $8,580,812$ billion rupiahs from the year 2011 to 2017 and has always increased every year. The value of GRDP in six provinces in Java always increases, where Jakarta has the highest GRDP in Java amounted to 1,381,523 billion rupiahs. Second place is East Java province with an average of $1,264,774$ billion rupiah, then amounted to 1,151,677 billion West Java and Central Java rupiah amounting to 767336 million. While the two provinces with the GRDP average of the lowest in the island of Java, Banten amounted to 348362 million and Yogyakarta Province amounted to 79768 million,

GRDP Yogyakarta Province is the lowest in Java, but the lowest growth rate of Yogyakarta Province is higher than Indonesia, namely in 2017 the economic growth rate of the Yogyakarta Province at 5.26 while Indonesia's growth rate amounted to 5.07. Yogyakarta also has a problem in per capita GRDP. The average of per capita GRDP 2011-2017 in Yogyakarta closed to 21,8 million rupiahs per year or the lowest rank among other provinces on Java Island.
According to [3] The GRDP per capita is one indicator of public welfare. The higher the GRDP per capita, the more prosperous residents of the area. It can be said that high public welfare, a high income and income distribution distributed across regions.

The gini index in Yogyakarta is highest on Java Island. it reaches 0.429 points, that figure is above the national average. According to Statistics of Indonesia, the range of numbers in the Gini index is between 0 to 1 . That is, the closer the number 0 , the lower inequality or evenly, and otherwise getting close to 1 , the higher the inequality or unequal.

Several studies that examine the relationship between economic growth and income inequality. [4] states that economic growth and income inequality have a complex relationship because it is difficult to understand and be controversial in empirical circles. [5] states that economic growth and income inequality have positive relationship. Neither the [6] states that in the long term relationship between economic growth and inequality of income is positive and significant.

[7] Summarized that in low-income countries between economic growth and inequality have a positive and negative correlation. And [8] states that in high-income countries have a positive relationship between inequality and economic growth.

The first economic growth in the early stages will increase along with the unequal distribution of income is also high up to a certain point, then on the next stage unequal distribution of income will begin to equity. This was later known as the Kuznets " Inverted U-Curve" because there is a change in the distribution of income for a certain period [9].

The purpose of this research is to identify and analyze the factors affecting income inequality in Yogyakarta 
Province in 2011-2017. This paper consist of the following sections; section 2 shows the research methods, section 3 presents, and reviews the results and discussion and section 4 presents the conclusion.

\section{RESEARCH METHOD}

This study used panel data which combines crosssection data of the five regencies/municipalities in the Yogyakarta Province and annual time series data, in 2011 to 2017. Data population, the GRDP, human development index, and the minimum wage in the five districts/cities in Yogyakarta Province using data released by Central Bureau of Statistics Indonesia through the publication of Statistics Indonesia.

The model used to see how the influence of the independent variable on the dependent variable in this study is the logarithm (Log) model.

$\log \mathrm{IG}_{\mathrm{it}}=\beta_{0}+\beta_{1} \log \mathrm{POP}_{\mathrm{it}}+\beta_{2} \log \mathrm{GRDP}_{\mathrm{it}}+\beta_{3} \log \mathrm{HDI}_{\mathrm{it}}+$ $\beta_{4} \log \mathrm{WAGE} \mathrm{it}_{\mathrm{i}}+\mu_{\mathrm{it}} \ldots$. (1)

Information :

$\begin{array}{ll}\log \mathrm{IG} & =\text { Logarithm Gini index } \\ \beta_{0} & =\text { constant } \\ \text { it } & =\text { Base Year } \\ \log (\mathrm{POP}) & =\text { Logarithm Population }\end{array}$

$\log (\mathrm{GRDB}) \quad=$ Logarithm of the Gross Domestic

Regional Product

$\log (\mathrm{HDI}) \quad=$ Logarithm of the Human

Development Index

$\log ($ WAGE $)=$ Logarithm of the minimum wage

Regency / City

$\mu$

$=$ Error Term

\section{RESULTS AND DISCUSSIONS}

To estimate the effect of income inequality on total inhabitants, the GRDP, the human development index, and the minimum wage districts/cities in 2011-2017, it is necessary to select the best model to be used in this study using the chow test and Hausman test as follows:

a. Chow test

In the chow test, there are two models to be chosen is the model common effect and fixed effect. If the result of the probability of the Chi-Squared is greater than 0.05 then the selected model of common effect whereas, if the probability of the Chi-Squared is less than 0.05 then the selected model is the fixed effect model. Based on the data that is done then the chow test results as follows: right then chow test results as follows:

Table 1. Test Results Chow

\begin{tabular}{|l|l|l|l|}
\hline Effect Test & \multicolumn{2}{c}{ Statistics } & df \\
\hline Cross-section F & 5.337910 & $(4.26)$ & 0.0028 \\
\hline Cross-section Chi-Square & 20.982671 & 4 & 0.0003 \\
\hline
\end{tabular}

Source: The results of data processing using E-Views 9

According the results of the above table it can be seen that the probability of a cross-section Chi-square of 0.0003 which is less than 0.05 , it can be decided $\mathrm{H} 0$ rejected and $\mathrm{H} 1$ accepted model chosen in this study is the fixed effect model, as selected fixed effect model will be needed Hausman test.

b. Hausman test
Hausman test is a step taken to select the model that should be used whether fixed effect or random effect. If the result of Chi-Square probability is greater than 0.05 , the model used random-effects models whereas if the Chi-Square probability smaller than 0.05 model used is the fixed effect. Based on the data if the following Hausman test results:

Table 2. Hausman Test Results

\begin{tabular}{|l|l|l|l|}
\hline Testisummary & Chi-Sq.Statistic & Chi-Sq.df & Prob.i \\
\hline Cross-section random & 21.351638 & 4 & 0.0003 \\
\hline
\end{tabular}

Source: The results of data processing using E-Views 9 
According to the table above can be seen the value of the probability of a random cross-section of 0.0044 is smaller than 0.05 so that the model should be selected is the fixed effect model.

Table 3. Results of Fixed Effect Model Estimation

\begin{tabular}{|c|c|c|c|}
\hline variable & Coefficient & t-Statistic & Prob. \\
\hline C & 32.47328 & 0.520857 & 0.6069 \\
\hline LogPOP & -0.759382 & -0.129259 & 0.8981 \\
\hline LogGRDP & -0.078755 & -0.054607 & 0.9569 \\
\hline LogHDI & -9.530272 & -3.233699 & 0.0033 \\
\hline LogWAGE & 1.382280 & 1.944732 & 0.0627 \\
\hline E-squared & Effects Specification \\
\hline Prob (F-statistic) & 0.784184 \\
\hline
\end{tabular}

Based on Table 3, then obtained the model as follows:

LogGI $=32.47328-0.759382 \quad \log \mathrm{POP} \quad-0.014668$

LogGRDP -9.530272 $\log$ HDI $+1.382280 \log \mathrm{WAGE}+\mu_{\mathrm{it}}$

\subsection{The Effect of Population on Income Inequality}

The results of the estimation model show that the population has an insignificant negative effect on the Gini index in the Yogyakarta Province in 2011-2017. Regression coefficients for the variables of the population show a negative sign of -0.759382 and a probability value of $0.8981>(0,05)$.

This result was driven by an increase in the population in Yogyakarta Province which led to intense competition for obtaining a job. The consequence is there are still people who are not absorbed by the labor market dan increased unemployment. That condition will decrease the productivity of the population and will be affected to per capita Gross Domestic Regional Product.

These results are the same as a research [10] which shows that population size has an insignificant negative effect on income inequality, this is due to increased unemployment which results in decreased population productivity and low per capita income. Then the results of this study are not following research [11], which states that numbers of population have a significant positive effect on income inequality, and [12] states that population has an significant positive effect on income inequality in Java. and [13] which states that population growth has a positive and insignificant effect on income inequality in Yogyakarta Province in 2007-2014.

\subsection{The Effect of GRDP on Income Inequality}

The results of the estimation model show that that the GRDP variable has an insignificant and a negative effect on the Gini index in the Yogyakarta Province in 2011-
2017. Regression coefficients for the variable of the GDRP showed a negative sign of -0.109132 and the probability of $0.9569>(0,05)$.

However, the estimation results of this study show that the GRDP variable is not significant, meaning that if there is an increase in GRDP it will not reduce the Gini index and income inequality in Yogyakarta Province will continue to occur. This is due to the geographical diversity factor, Yogyakarta City is the economic center of Yogyakarta Province whose economic growth is faster than Kulon Progo, Gunung Kidul, Bantul, and Sleman Regencies. The four districts still have rural areas and on average the population still works in the agricultural sector.

This study is not in line consistent with [14] stated that economic growth significantly affects income inequality. But this study is in line with the [15] stated that economic growth has an insignificant negative effect on the unequal distribution of income.

\subsection{The Effect of Human Development Index on Income Inequality}

From the results of the estimation model known that the human development index variable has a significant and has a negative effect on the Gini index in the Yogyakarta Province in 2011-2017. Regression coefficients for the variables of human development index show a negative sign of by -9.530272 and probability value of $0.0033<(0: 05)$, This suggests that any improvement in the human development index by $1 \%$ would lower the Gini index of $9.53 \%$, which means that income inequality in the Yogyakarta Province will be more evenly distributed.

The results of this study are not consistent with [16] which states that HDI has a significant positive effect on the inequality of income distribution in Yogyakarta. These results are in line with [17] who stated that the human development index has a significant negative 
effect on unequal income distribution. If the human development index has a negative effect on income inequality, it is because there is an important role in education in increasing labor productivity, especially graduates from higher education levels.

\subsection{The Effect of Minimum Wages Regency/City on Income Inequality}

According the results of the estimation model show that the minimum wage variable district/city has an insignificant and a positive effect on the Gini index in the Yogyakarta Province in 2011-2017. Regression coefficients for the variables minimum wage districts/cities showed positive sign of 1.382280 and a probability value of 0.0627 .

This study is not consistent with [18] stated that the regional minimum wage an insignificant negative effect on income inequality in the District/Town in South Sulawesi province. However, the results of this study are the same as for [19] stated that the wage variable has significant and positive impact in Central Java province. and [20] also stated that there is a positive relationship between income inequality and the minimum wage, where the higher in the minimum wage will increase inequality.

The minimum wage will have an impact on wages distribution in two ways: direct impacts where the higher the wages of workers who earn low wages (less than minimum wage) into compliance with the provincial minimum wage and that both the indirect impact which the minimum wage policy will increase the wages of workers revenue was greater than the minimum wage [21], This is consistent with the neoclassical theory which states that the increase in the minimum wage will increase income inequality, as a non-market will be instrumental in setting the minimum threshold in the labor market so that it will lead to a reduction in the demand for labor and the unemployed.

\section{CONCLUSION}

The Population has a negative effect and not significant on The Gini index in Yogyakarta Province, for the year 2011-2015 there is still a lot of poor people increased every year. Besides, there are many people not in the labor force in 2017 as many as 843017 thousand people and the number of unemployed in 2017 amounted to 64017 thousand people. GRDP variables has a negative impact and not significant effect on the Gini index in Yogyakarta Province. This is because there are geographical differences between districts/cities.

HDI has an significant negative effect on Gini index in Yogyakarta Province. This is evident by the amount of labor in the province of Yogyakarta which has an average education of the latest University and Graduate School.
Minimum Wage has a positive effect and not significant to the Gini index in Yogyakarta Province. This is because there are still many low-educated people working in the informal sector, such as street vendors. Therefore, Therefore, there is a large difference between income in the formal and informal sectors. This condition occurs in Kulon Progo and Gunung Kidul.

\section{REFERENCES}

[1] M. P. Todaro, Pembangunan Ekonomi di Dunia Ketiga, Edisi Ketu. Jakarta: Penerbit Erlangga, 2000.

[2] M. Kuncoro, Otonomi dan Pembangunan Daerah, Reformasi, Perencanaan, Strategi dan Peluang. Jakarta: Erlangga, 2004.

[3] S. Thamrin, Analisis Potensi Pendapatan Asli Daerah, Bunga Rampai Manajemen Keuangan Daerah. Yogyakarta: UPP AMP YKPN, 2001.

[4] S. J. Turnovsky, "Economic Growth and Inequality: The Role of Pubilc Investment," $J$. Econ. Dyn. Control, no. 61, 2015, pp. 204-221.

[5] L. Lundberg, M and Squire, "The Simultaneous Evolution of Growth and Inequality," Econ. J., vol. 113, no. 487, 2003, pp. 326-344.

[6] W. A. Risso and E. J. S. Carrera, "Inequality and economic growth in China," J. Chinese Econ. Foreign Trade Stud., vol. 5, no. 2, 2012, pp. 80-90, doi: 10.1108/17544401211233453.

[7] C. . Huang, H. C. R, Fang, W., Miller, S.M., and Yeh, "The Effect of Growth volatility on income inequality," Econ. Model., no. 45, 2015, pp. 212 222.

[8] V. J. Fawaz, F., Rahmana, M., \& Valcarcel, “A refinement of the relationship between economic growth and income inequality," Appl. Econ., vol. 46, no. 27, 2014, pp. 3351-3361.

[9] K. Simon, "Economic Growth and Income Inequality,” Am. Econ. Rev., vol. XLV March, 1955.

[10] M. Arif and R. A. Wicaksani, "Ketimpangan Pendapatan Propinsi Jawa Timur dan Faktor- faktor yang Mempengaruhinya," Urecol, 2017, pp. 323 328.

[11] R. Bayhaqi, "Analisis Ketimpangan Pendapatan Penduduk di Kalimantan Barat Tahun 2010-2015,' 2018.

[12] Y. Del Rosa and I. Sovita, “Analisis Faktor-Faktor Yang Mempengaruhi Ketimpangan Distribusi Pedapatan di Pulau Jawa," Menara Ekon., vol. II, no. 4, 2016, pp. 41-52.

[13] D. Aggina and W. D. Artaningtyas, "Pengaruh 
Pertumbuhan Ekonomi, Pertumbuhan Penduduk, Pertumbuhan Investasi, dan Indeks Pembangunan Manusia Terhasap Ketimpangan Distribusi Pendapatan di Daerah Istimewa Yogyakarta Tahun 2007-2014," Buleti Ekon., vol. 15, no. 1, 2017, pp. 1-154.

[14] Y. E. Putri, S. Amar, and H. Aimon, "Analisis Faktor-Faktor Yang Mempengaruhi Pertumbuhan Ekonomi Dan Ketimpangan Pendapatan Di Indonesia," J. Kaji. Ekon., vol. 3, no. 6, 2015.

[15] D. Anggiat Mugabe Damanik, "Faktor-faktor yang mempengaruhi ketimpangan pendapatan melalui pertumbuhan ekonomi di Provinsi Jambi," e-Jurnal Perspekt. Ekon. dan Pembang. Drh. Vol. 7 No.1, vol. 7, no. 1, 2018 pp. 15-25.

[16] R. D. Astuti, “Analisis determinan ketimpangan distribusi pendapatan di daerah istimewa yogyakarta periode 2005-2013," 2015, pp. 1-75.

[17] M. Robby, "Pengaruh Investasi dan Indeks Pembangunan Manusia terhasap Ketimpangan Distribusi Pendapatan Antar Daerah di Kalimantan Barat," J. Mhs. Ekon. Pembang., vol. Vol 7 No 2, 2018.

[18] Zulkifli, "Pengaruh Upah Minimum Regional (UMR) dan Kontribusi Sektor industri Terhasap Ketimpangan Distribusi Pendapatan di Sulawesi Selatan," Econ. Sos. Dev., vol. 3, no. 1, 2016.

[19] R. Abdulah, "Faktor-Faktor Yang Memengaruhi Ketimpangan Pendapatan Di Jawa Tengah," Jejak (Jurnal Ekon. dan Kebijakan), vol. 6, no. 1, 2013, pp. 42-53, doi: 10.15294/jejak.v6i1.3747.

[20] N. M. N. Sari Nurmalisa Sungkar, "Pengaruh Upah Minimum Terhasap Ketimpangan Pendapatan Di Indonesia.," J. Ilmu Ekon. Progr. Pascasarj. Unsyiah, vol. 3, no. 2, 2016, pp. 40-53,

[21] M. Campolieti, R. Hebdon, and B. Dachis, "The impact of collective bargaining legislation on strike activity and wage settlements," Ind. Relat. (Berkeley)., vol. 53, no. 3, 2014, pp. 394-429. doi: 10.1111/irel.12063. 